\title{
THE PRIORITY FOR IMPROVEMENT VEHICLE PARKING SERVICE AT EL TARI KUPANG AIRPORT USING QUALITY FUNCTION DEPLOYMENT (QFD).
}

\author{
Amy Wadu ${ }^{1}$ Achmad Wicaksono ${ }^{2}$ \\ ${ }^{1}$ Civil Engineering Department, Kupang State Polytechnic, Kupang, 85258, Indonesia \\ ${ }^{2}$ Civil Engineering Department, Brawijaya University, Malang, 65145, Indonesia \\ e-mail : awd.ub15@gmail.com
}

\begin{abstract}
El Tari Kupang Airport is one of the airports in the Province of East Nusa Tenggara (NTT) with a growing rate of passenger movement increasing every year. In line with the increase in passenger movement growth, the use of vehicles to enter the airport area is increasing. This results in the need for handling parking facilities to provide proper security and comfort to airport visitors. The method used in this research is the Quality Function Deployment (QFD) method to determine the priority of parking service handling. Based on the results of QFD, the priority order for handling that must be immediately implemented is to provide training to parking officers so that they have the ability to manage traffic in the parking area.
\end{abstract}

Keywords: Airport, Quality Function Deployment (QFD), Parking, Service

\section{Introduction}

Transportation is one of the services in the service sector that cannot be separated from human activities today. Smooth inter-regional, inter-island relations will be the main door in triggering the development of an area. The need for a mode of transportation that is comfortable, safe, and fast is the basis for choosing the mode of transportation [1] [2] . In the current era of globalization, all sectors demand a process that occurs quickly, as well as the transportation sector. Air transportation is a favorite when traveling long distances because it takes less time than other modes of transportation. During the last three decades of the twentieth century, the worldwide long-term growth rate for passenger aircraft was about 6 percent per year [3]. So that the development of air transportation activities is currently increasing rapidly. To accommodate this growth, airports must add facilities or improve the performance of existing facilities for the better. If the facilities provided cannot keep up with growing demand, then capacity and service problems can occur starting from parking facilities and airport entrances, terminals, aprons, taxiways, to runways [4].

The problem occurred at El Tari Kupang airport when private vehicles, both cars and motorbikes, became the main choice for almost all airport visitors to enter and exit the airport area. Taxis are the only transportation provided by the operational party that travelers can use for access in and out of the airport. However, because the price is considered quite expensive compared to using private vehicles, many visitors and passengers are reluctant to use this taxi service. This is of course different from conditions in developed countries where people prefer to use public transportation because the convenience factor provided by public transportation is more than private transportation [5]. So that during rush hour it is difficult to get a parking location for drivers to park their vehicles.

Another problem that often occurs at El Tari Kupang airport is that many private vehicle drivers park their vehicles in an orderly manner, both two-wheeled and four-wheeled, ignoring the presence of parking prohibition signs. When motorists park their vehicles, they seem in a hurry, but in the end 
the vehicle is parked for hours. There are also vehicles parked by visitors in front of departures and arrival areas, which park for hours. Of course this is very disturbing the movement around the area. Whereas the existence of an activity should be as minimal as possible to cause disruption of traffic flow in the vicinity [6]. With the provision of good facilities, it will not cause conflicts in the surrounding traffic flow [7]. In addition, other anticipatory steps that need to be taken are controlling parking spaces with various policies, such as policies regarding parking, time policies, and restrictions on parking spaces [8].

The QFD method is used in the process of planning and developing the quality of service according to the needs and desires of the user. QFD can be interpreted as the distribution of variables related to product development and quality that meets user satisfaction. The basic principle of QFD is to capture the voice of the user (voice of customer) and ensure that the user's needs can be translated into the right strategies, products and processes. The purpose of this QFD is not only to meet the expectations of the user, but also to try to exceed these expectations so that later the user does not reject or complain, but instead the user wants it [9] [10].

Based on the description above, it is necessary to conduct research with the title "The Priority For Improvement Vehicle Parking Service At El Tari Kupang Airport Using Quality Function Deployment (QFD)" so that later recommendations for handling will be obtained in order to help create a safe, comfortable, and orderly parking area.

\section{Methods}

The questionnaire in this study will be distributed to airport visitors who are users of parking facilities at El Tari Kupang Airport. The distribution of this questionnaire aims to obtain complete information as needed accurately which will later be used to assess the satisfaction level of parking service users using the IPA (Importance Performance Analysis) method and followed by the QFD (Quality Function Deployment) method.

\subsection{Sample}

Population is a group of people in an area or object under study who will be given a questionnaire with a number of questions according to predetermined variables. The population used in this study were airport visitors who were generally airplane passengers at El Tari Kupang Airport. Based on the latest data released by BPS NTT, the number of passengers in September 2016 was 169079 passengers. So the average number of passengers in one week is 42270 passengers.

The number of samples given by the questionnaire must be representative of the existing population. This sample size calculation uses the Solvin method, with the following formula.

$\mathrm{n}=\frac{\mathrm{N}}{1+\mathrm{Ne}^{2}}$

Where,

$\mathrm{n}=$ sample size

$\mathrm{N}=$ population size $(42270)$

$\mathrm{e}=$ error rate $(5 \%)$

then the number of samples obtained is \pm 400 samples per week

At the data processing stage, the level of effectiveness of the parking policy is carried out using the IPA (Importance Performance Analysis) and QFD (Quality Function Deployment) methods.

\subsection{Parking Service Assessment Variables}

The variables in the study were taken by adopting items related to the operation of parking facilities in parking parks in the Guidelines. Planning and. Operation of Parking Facilities in 1998 issued by the Directorate of City Transportation Traffic System, Directorate General of Land Transportation by adding several sub-variables from regulations relating to parking at airports. The study variables used in this study, among others.

1. Parking Policy

a. Determination of basic optimal parking rates (Guidelines. Planning and Operation of Parking Facilities, 1998) 
b. Limitation of parking locations with parking restrictions (Guidelines. Planning and Operation of Parking Facilities, 1998)

c. Determination of progressive rates according to parking duration (Guidelines. Planning and Operation of Parking Facilities 1998)

d. Determination of the ticket system (Guidelines. Planning and. Operation of Parking Facilities, 1998)

2. Parking lot

a. Ease of reach by service users (Minister of Transportation Decree Number KM 66 of 1993 concerning Public Parking Facilities)

b. The parking lot is regulated by circulation and vehicle parking position which is stated by traffic signs or road markings (Minister of Transportation Decree Number KM 66 of 1993 regarding Parking Facilities for Public)

c. Each location used to park a vehicle is marked with a letter or number which makes it easy for service users to find their vehicle (Minister of Transportation Decree Number KM 66 of 1993 concerning Public Parking Facilities)

d. Cleanliness of the parking lot (Decree of the Director General of Land Transportation No. 72 / hk.105 / drjd / 96 concerning Technical Guidelines for the Implementation of Parking Facilities)

e. Parking pavement conditions (Decree of the Director General of Land Transportation No. 72 / hk.105 / drjd / 96 concerning Technical Guidelines for the Implementation of Parking Facilities)

f. Parking capacity according to standards (Minister of Transportation Regulation No. PM 49 of 2012 concerning Standard Service for Economy Class Passengers of Domestic Scheduled Commercial Air Transport)

g. Parking area according to standard (Minister of Transportation Regulation No. PM 49 of 2012 concerning Standard Service for Economy Class Domestic Scheduled Commercial Air Transport)

h. Sufficient vehicle-free space (Guidelines. Planning and Operation of Parking Facilities, 1998)

i. Regular parking patterns (Guidelines. Planning and Operation of Parking Facilities, 1998)

j. Smooth circulation paths, aisles, and modules (Guidelines. Planning and Operation of Parking Facilities, 1998)

3. Parking Supervision

a. Parking supervision of parking violations (Guidelines. Planning and Operation of Parking Facilities, 1998)

b. Vehicle safety and parked equipment (Guidelines. Planning and Operation of Parking Facilities, 1998)

c. The ability of parking attendants to guide drivers into and out of parking lots (Guidelines. Planning and Operation of Parking Facilities, 1998)

d. The ability of parking attendants to regulate traffic in the parking area (Guidelines. Planning and Operation of Parking Facilities, 1998)

e. The ability of parking attendants to direct the procedures for parking the vehicle (Guidelines. Planning and Operation of Parking Facilities, 1998)

f. Parking attendant behavior in dealing with parkers (Guidelines. Planning and Operation of Parking Facilities, 1998) 
4. Parking Support Facilities

a. Officer post (Decree of the Minister of Transportation Number KM 66 of 1993 regarding Parking Facilities for Public)

b. Lighting lamps (Decree of the Minister of Transportation Number KM 66 of 1993 regarding Parking Facilities for Public)

c. Exits and entrances (Decree of the Minister of Transportation Number KM 66 of 1993 regarding Parking Facilities for Public)

d. Electronic timekeeping device (Minister of Transportation Decree Number KM 66 of 1993 concerning Public Parking Facilities)

e. Electronic door (Decree of the Minister of Transportation Number KM 66 of 1993 regarding Parking Facilities for the Public)

\subsection{QFD (Quality Function Deployment) Analysis}

QFD analysis will give priority to handling service performance that is included in quadrant I of IPA analysis [11], which quadrant $I$ is a service that has a low level of performance but is felt to have a high level of importance.

\section{Result and Discussion}

Based on the results of Importance Performance Analysis (IPA) in previous studies [11], the service attributes that are included in quadrant I will then become input data on Quality Function Deployment (QFD). The service attributes in question are:

- The ability of the parking attendant to direct the procedures for parking the vehicle $\left(\mathrm{x}_{19}\right)$

- The ability of the parking attendant to manage traffic in the parking area $\left(\mathrm{x}_{18}\right)$

- The ability of parking attendants to guide drivers into and out of parking lots $\left(\mathrm{x}_{17}\right)$

- Parking supervision of parking violations $\left(\mathrm{x}_{15}\right)$

- Parking attendant behavior in dealing with parkers $\left(\mathrm{x}_{20}\right)$

- The parking lot is regulated by circulation and the position of the parking lot for the vehicle as stated by traffic signs or road markings $\left(\mathrm{x}_{6}\right)$

- Regular parking pattern $\left(\mathrm{x}_{13}\right)$

The next stage that must be carried out is to conduct a Quality Function Deployment (QFD) analysis to determine the corrective steps that need to be taken to improve the performance of these service attributes so as to provide more satisfaction to airport visitors.

\subsection{Voice of Customer (VoC)}

$\mathrm{VoC}$ is an attribute obtained from quadrant I which is the result of Importance Performance Analysis (IPA). This VoC will be a question for the manager of the El Tari Kupang Airport Vehicle Parking.

Table 1. Voice of Customer (VoC) Data

\begin{tabular}{cl}
\hline No & \multicolumn{1}{c}{ Voice of Customer } \\
\hline 1 & $\begin{array}{l}\text { The ability of the parking attendant to direct the procedures } \\
\text { for parking the vehicle (x19) }\end{array}$ \\
2 & $\begin{array}{l}\text { The ability of the parking attendant to manage traffic in the } \\
\text { parking area (x18) }\end{array}$ \\
3 & $\begin{array}{l}\text { The ability of parking attendants to guide drivers into and out } \\
\text { of parking lots (x17) }\end{array}$
\end{tabular}




\begin{tabular}{cl}
\hline No & \multicolumn{1}{c}{ Voice of Customer } \\
\hline 4 & Parking supervision of parking violations (x15) \\
5 & Parking attendant behavior in dealing with parkers (x20) \\
6 & The parking lot is regulated by circulation and the position of \\
& parking for vehicles, which is stated by traffic signs or road \\
& markings (x6) \\
7 & Regular parking pattern (x13) \\
\hline
\end{tabular}

\subsection{Planning Matrix.}

There are several parts that constitute a planning matrix (Planning Matrix), the parts in question are:

3.2.1. Importance to Customer

The average importance value of service attributes entered in quadrant $I$ in the Importance Performance Analysis (IPA) is used as the Importance to Customer value

Table 2. Importance of Customer

\begin{tabular}{|c|c|c|}
\hline No & Voice of Customer & $\begin{array}{c}\text { Importance to } \\
\text { Customer }\end{array}$ \\
\hline 1 & $\begin{array}{l}\text { The ability of the parking attendant to direct the procedures } \\
\text { for parking the vehicle (x19) }\end{array}$ & 4,65 \\
\hline 2 & $\begin{array}{l}\text { The ability of the parking attendant to manage traffic in the } \\
\text { parking area (x18) }\end{array}$ & 4,63 \\
\hline 3 & $\begin{array}{l}\text { The ability of parking attendants to guide drivers into and out } \\
\text { of parking lots (x17) }\end{array}$ & 4,63 \\
\hline 4 & Parking supervision of parking violations (x15) & 4,64 \\
\hline 5 & Parking attendant behavior in dealing with parkers (x20) & 4,68 \\
\hline 6 & $\begin{array}{l}\text { The parking lot is regulated by circulation and the position of } \\
\text { parking for vehicles, which is stated by traffic signs or road } \\
\text { markings (x6) }\end{array}$ & 4,51 \\
\hline 7 & Regular parking pattern (x13) & 4,56 \\
\hline
\end{tabular}

\subsubsection{Customer Satisfaction Performance}

The average value of the satisfaction level of the service attributes included in quadrant I in the Importance Performance Analysis (IPA) [11] is used as the value of Customer Satisfaction Performance

Table 3. Customer Satisfaction Performance

\begin{tabular}{clc}
\hline No & Voice of Customer & $\begin{array}{c}\text { Customer Satisfaction } \\
\text { Performance }\end{array}$ \\
\hline 1 & $\begin{array}{l}\text { The ability of the parking attendant to direct the procedures } \\
\text { for parking the vehicle (x19) }\end{array}$ & 1,92
\end{tabular}




\begin{tabular}{clc}
\hline No & \multicolumn{1}{c}{ Voice of Customer } & $\begin{array}{c}\text { Customer Satisfaction } \\
\text { Performance }\end{array}$ \\
\hline 2 & $\begin{array}{l}\text { The ability of the parking attendant to manage traffic in the } \\
\text { parking area (x18) }\end{array}$ & 1,98 \\
3 & $\begin{array}{l}\text { The ability of parking attendants to guide drivers into and out } \\
\text { of parking lots (x17) }\end{array}$ & 2,02 \\
4 & $\begin{array}{l}\text { Parking supervision of parking violations (x15) } \\
5\end{array}$ & 2,10 \\
6 & $\begin{array}{l}\text { Parking attendant behavior in dealing with parkers (x20) } \\
\text { parking for vehicles, which is stated by traffic signs or road }\end{array}$ & 2,49 \\
& $\begin{array}{l}\text { markings (x6) } \\
7\end{array}$ & Regular parking pattern (x13) \\
\hline
\end{tabular}

\subsubsection{Goal}

The goal is obtained from the highest score on the average level of importance, as shown in table

Table 4. Goal

\begin{tabular}{|c|c|c|c|c|}
\hline No & Voice of Customer & $\begin{array}{l}\text { Customer } \\
\text { Satisfaction } \\
\text { Performance }\end{array}$ & $\begin{array}{l}\text { Importance to } \\
\text { Customer }\end{array}$ & Goal \\
\hline 1 & $\begin{array}{l}\text { The ability of the parking attendant to } \\
\text { direct the procedures for parking the } \\
\text { vehicle (x19) }\end{array}$ & 1,92 & 4,65 & 4,65 \\
\hline 2 & $\begin{array}{l}\text { The ability of the parking attendant to } \\
\text { manage traffic in the parking area }(x 18)\end{array}$ & 1,98 & 4,63 & 4,63 \\
\hline 3 & $\begin{array}{l}\text { The ability of parking attendants to } \\
\text { guide drivers into and out of parking lots } \\
\text { (x17) }\end{array}$ & 2,02 & 4,63 & 4,63 \\
\hline 4 & $\begin{array}{l}\text { Parking supervision of parking } \\
\text { violations }(\mathrm{x} 15)\end{array}$ & 2,10 & 4,64 & 4,64 \\
\hline 5 & $\begin{array}{l}\text { Parking attendant behavior in dealing } \\
\text { with parkers (x20) }\end{array}$ & 2,49 & 4,68 & 4,68 \\
\hline 6 & $\begin{array}{l}\text { The parking lot is regulated by } \\
\text { circulation and the position of parking } \\
\text { for vehicles, which is stated by traffic } \\
\text { signs or road markings }(x 6)\end{array}$ & 2,64 & 4,51 & 4,51 \\
\hline 7 & Regular parking pattern (x13) & 2,91 & 4,56 & 4,56 \\
\hline
\end{tabular}

\subsubsection{Improvement Ratio}

This Improvement Ratio is obtained from the results for the goals with the average level of service satisfaction. Improvement Ratio shows how much effort was made to improve services in quadrant I Importance Performance Analysis (IPA) [11]. 
Table 5. Improvement Ratio

\begin{tabular}{|c|c|c|c|}
\hline No & Voice of Customer & Goal & IR \\
\hline 1 & $\begin{array}{l}\text { The ability of the parking attendant to direct the procedures } \\
\text { for parking the vehicle (x19) }\end{array}$ & 4,65 & 2,42 \\
\hline 2 & $\begin{array}{l}\text { The ability of the parking attendant to manage traffic in the } \\
\text { parking area (x18) }\end{array}$ & 4,63 & 2,34 \\
\hline 3 & $\begin{array}{l}\text { The ability of parking attendants to guide drivers into and out } \\
\text { of parking lots (x17) }\end{array}$ & 4,63 & 2,29 \\
\hline 4 & Parking supervision of parking violations (x15) & 4,64 & 2,22 \\
\hline 5 & Parking attendant behavior in dealing with parkers (x20) & 4,68 & 1,88 \\
\hline 6 & $\begin{array}{l}\text { The parking lot is regulated by circulation and the position of } \\
\text { parking for vehicles, which is stated by traffic signs or road } \\
\text { markings (x6) }\end{array}$ & 4,51 & 1,71 \\
\hline 7 & Regular parking pattern (x13) & 4,56 & 1,56 \\
\hline
\end{tabular}

3.2.5. Raw Weight

The Raw Weight value is obtained from the multiplication result between the Goal and Improvement Ratio shown in the Table 6.

Table 6. Raw Weight

\begin{tabular}{llccc}
\hline No & \multicolumn{1}{c}{ Voice of Customer } & Goal & IR & RW \\
\hline 1 & $\begin{array}{l}\text { The ability of the parking attendant to direct the } \\
\text { procedures for parking the vehicle (x19) }\end{array}$ & 4,65 & 2,42 & 11,26 \\
$2 \quad \begin{array}{l}\text { The ability of the parking attendant to manage traffic } \\
\text { in the parking area (x18) }\end{array}$ & 4,63 & 2,34 & 10,83 \\
$3 \quad \begin{array}{l}\text { The ability of parking attendants to guide drivers into } \\
\text { and out of parking lots (x17) }\end{array}$ & 4,63 & 2,29 & 10,60 \\
$4 \quad \begin{array}{l}\text { Parking supervision of parking violations (x15) } \\
5\end{array}$ & 4,64 & 2,22 & 10,29 \\
$\begin{array}{l}\text { Parking attendant behavior in dealing with parkers } \\
\text { (x20) }\end{array}$ & 4,68 & 1,88 & 8,80 \\
$\quad \begin{array}{l}\text { The parking lot is regulated by circulation and the } \\
\text { position of parking for vehicles, which is stated by } \\
\text { traffic signs or road markings (x6) }\end{array}$ & 4,51 & 1,71 & 7,71 \\
$\quad \begin{array}{l}\text { Regular parking pattern (x13) } \\
7\end{array}$ & 4,56 & 1,56 & 7,12 \\
\hline
\end{tabular}

\subsubsection{Normalized Raw Weight (NRW)}

The Normalized Raw Weight (NRW) value is obtained by dividing each Raw Weight (RW) value by the total RW value 
Table 7. Normalized Raw Weight

\begin{tabular}{|c|c|c|c|}
\hline No & Voice of Customer & RW & NRW \\
\hline 1 & $\begin{array}{l}\text { The ability of the parking attendant to direct the procedures } \\
\text { for parking the vehicle (x19) }\end{array}$ & 11,26 & 0,17 \\
\hline 2 & $\begin{array}{l}\text { The ability of the parking attendant to manage traffic in the } \\
\text { parking area (x18) }\end{array}$ & 10,83 & 0,16 \\
\hline 3 & $\begin{array}{l}\text { The ability of parking attendants to guide drivers into and out } \\
\text { of parking lots (x17) }\end{array}$ & 10,60 & 0,16 \\
\hline 4 & Parking supervision of parking violations (x15) & 10,29 & 0,15 \\
\hline 5 & Parking attendant behavior in dealing with parkers (x20) & 8,80 & 0,13 \\
\hline 6 & $\begin{array}{l}\text { The parking lot is regulated by circulation and the position } \\
\text { of parking for vehicles, which is stated by traffic signs or } \\
\text { road markings (x6) }\end{array}$ & 7,71 & 0,12 \\
\hline 7 & Regular parking pattern (x13) & 7,12 & 0,11 \\
\hline & Total & 66,61 & \\
\hline
\end{tabular}

3.2.7. Technical Response

Technical responses are also called the how's which are answers to question items from the Voice of Customer or also called the what's. The how's was obtained from the results of interviews with the parking manager at El Tari Kupang Airport. The technical response that has been obtained is:

\begin{tabular}{clcll}
\hline No. & \multicolumn{1}{c}{ Questions } & No. & \multicolumn{1}{c}{ Responds } \\
\hline 6 & $\begin{array}{l}\text { The parking lot is regulated by } \\
\text { circulation and the position of parking for } \\
\text { vehicles, which is stated by traffic signs } \\
\text { or road markings }\end{array}$ & 1 & $\begin{array}{l}\text { Complete road signs and markings } \\
\text { Maintain signs and markers }\end{array}$ \\
13 & Regular parking pattern & 3 & $\begin{array}{l}\text { Circulation and parking design } \\
\text { improvements }\end{array}$ \\
15 & $\begin{array}{l}\text { Parking supervision against parking } \\
\text { violations }\end{array}$ & 4 & $\begin{array}{l}\text { Conduct briefings to parking attendants to } \\
\text { be more assertive against parking } \\
\text { offenders }\end{array}$ \\
17 & 5 & $\begin{array}{l}\text { Imposing sanctions in the form of fines } \\
\text { for parking offenders } \\
\text { The parking attendant's ability to guide } \\
\text { drivers into and out of the parking lot }\end{array}$ & 6 & $\begin{array}{l}\text { Provide training to parking attendants so } \\
\text { inat they have the ability to guide drivers } \\
\text { in and of parking lots } \\
\text { Adding parking attendant personnel }\end{array}$ \\
18 & $\begin{array}{l}\text { The parking attendant's ability to manage } \\
\text { traffic in the parking area }\end{array}$ & 8 & $\begin{array}{l}\text { Provide training to parking attendants so } \\
\text { that they have the ability to manage traffic } \\
\text { in the parking area }\end{array}$
\end{tabular}




\begin{tabular}{llll}
\hline No. & \multicolumn{1}{c}{ Questions } & No. & \multicolumn{1}{c}{ Responds } \\
\hline 19 & 9 & $\begin{array}{l}\text { Do a comparative study to other places } \\
\text { that have a good parking system }\end{array}$ \\
$\begin{array}{l}\text { The ability of the parking attendant to procedures for parking the } \\
\text { vehicle }\end{array}$ & 10 & $\begin{array}{l}\text { Provide training to parking attendants on } \\
\text { the ability to direct proper vehicle parking } \\
\text { procedures }\end{array}$ \\
$20 \quad \begin{array}{l}\text { Parking attendant behavior in dealing } \\
\text { with parkers }\end{array}$ & 11 & $\begin{array}{l}\text { Provide more direction to officers to } \\
\text { prioritize services to parking users }\end{array}$ \\
\hline
\end{tabular}

\subsection{House of quality (HoQ)}

Relation Matrix is a matrix that shows the relationship between what's and the how's. In determining the relationship, four forms of relationship are used, namely:

- Strong relationships are given the symbol $(\bullet)$ with a weight of 9

- Relationships are being given the symbol ( $(0)$ with a weight of 3

- Weak relationships are given the symbol $(\Delta)$ with a weight of 1

- Weak relationships are not given the symbol () with a weight of 0

Correlation Matrix describes the relationship between technical responses (the how's) which will get the overall decision result which is determined in the form of the following relationship.

- Negative relationship / no relationship is symbolized (-)

- Positive relationships are symbolized $(+)$

- Very positive relationship is symbolized $(++)$

The Technical Matrix provides a performance target that will be done to address the item's question of what's. This target is set based on the how's items which are sorted by priority handling. This priority value is obtained from the Normalized Contribution.

Overall, all the stages of Quality Function Deployment (QFD) can be seen in the House of Quality (HoQ) in the image below. 


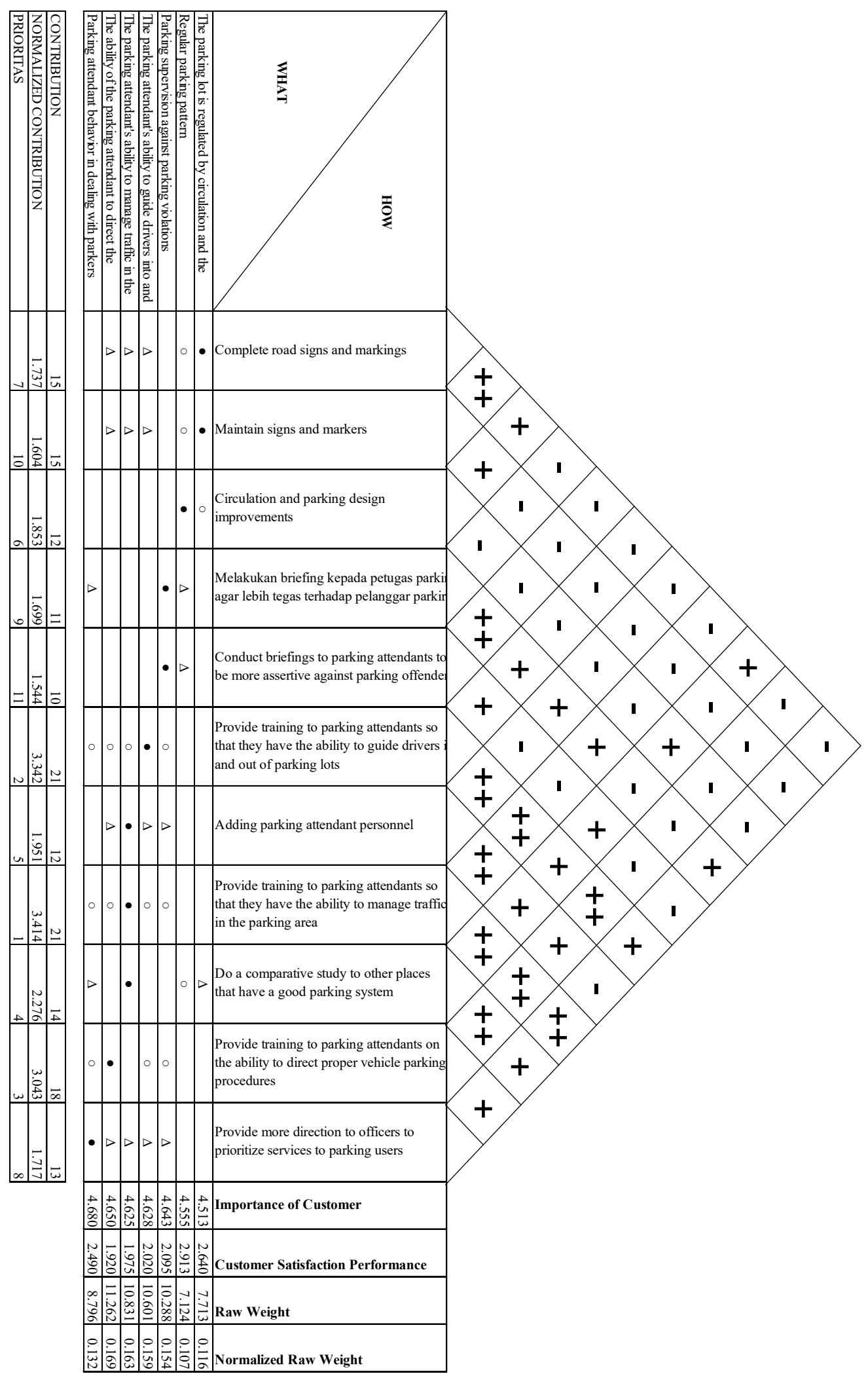

Figure 1. House of quality (HoQ) 


\subsection{Priority for handling parking services}

Based on the Normalized Contribution value shown in Figure 5.50, the priority for handling parking services is determined as follows:

1. Provide training to parking officers so that they have the ability to manage traffic in the parking area $(3,414)$.

This responds to the low satisfaction of airport visitors with parking attendant performance related to the ability to manage traffic. Providing training will certainly increase the ability of parking attendants and will make parking attendants more responsive to traffic obstacles in the parking area.

2. Provide training to parking officers so that they have the ability to guide drivers into and out of parking lots $(3,342)$.

This responds to the low satisfaction of airport visitors with the performance of parking attendants in guiding drivers into and out of parking lots. Providing training will certainly increase the ability of officers to better guide drivers in and out of parking lots.

3. Providing training to parking officers on the ability to direct good vehicle parking procedures (3.043).

This responds to the low satisfaction of airport visitors with the performance of parking attendants in directing the procedures for parking vehicles. Providing training will certainly improve the quality of parking attendants in directing good vehicle parking procedures so that there is order in parking the vehicle.

4. Conduct a comparative study to other places with good parking systems $(2,276)$.

This will answer the low visitor satisfaction with the quality of parking attendants in regulating parking circulation. By conducting a comparative study to other places, a good parking management procedure will be adopted in terms of the officers and existing facilities.

5. Adding parking attendant personnel $(1,951)$

This will answer the low satisfaction of airport visitors with the ability of parking attendants to manage traffic in the parking area. By adding parking attendant personnel, of course, it will provide better service to parking visitors.

6. Improved circulation and parking design $(1,853)$

This will answer the low satisfaction of airport visitors with regular parking patterns. With this improvement in the circulation and parking lot design, airport visitors can get easier access to all parking locations so that the existing parking capacity can be used more optimally.

7. Completing road signs and markings $(1,737)$

This will answer the low satisfaction of airport visitors with the parking lot facilities, regulated circulation and vehicle parking positions as indicated by traffic signs or road markings. By completing signs and road markings, it will be more communicative with the aim of guiding visitors to the desired facilities.

8. Provide more direction to officers to prioritize services to parking users $(1,717)$.

This will answer the low satisfaction of airport visitors with parking attendant behavior in dealing with parkers. By providing directions to prioritize officer services, it will be more responsive to the needs of parking users and provide more comfort while in parking facilities.

9. Briefing parking attendants to be more assertive against parking offenders $(1,699)$

This will answer the low satisfaction of airport visitors with the performance of parking attendants in parking supervision of parking violations. By giving a briefing to the officers, it is 
hoped that the officers can be more assertive in reprimanding parking offenders to park their vehicles in their proper places.

10. Maintain signs and markers $(1,604)$

This will answer the low satisfaction of airport enders with the parking lot regulated by circulation and vehicle parking positions as stated by traffic signs or road markings. By taking care of these signs and markers, parkers will better understand the direction and purpose of the parking facilities they are aiming for.

11. Imposing sanctions in the form of fines for parking offenders $(1,544)$

This will answer the low satisfaction of airport visitors with parking supervision of parking violations. By providing sanctions in the form of fines, it is hoped that parking violators will get a deterrent effect for committing parking violations.

\section{Conclutions}

Based on the QFD analysis the service variables that need handling are determined based on the highest to the lowest Normalized Constribution value are as follows:

1. Provide training to parking officers so that they have the ability

a. Regulating traffic in the parking area $(3,414)$

b. Guiding drivers in and out of parking lots $(3,342)$,

c. Directing good vehicle parking procedures (3.043)

2. Conducting a comparative study to other places that have a good parking system $(2,276)$,

3. Adding parking attendant personnel $(1,951)$

4. Improved circulation and parking design $(1,853)$

5. Completing road signs and markings $(1,737)$

6. Provide more direction to officers to prioritize services to parking users $(1,717)$

7. Conduct briefings to parking attendants to be firmer against parking offenders $(1,699)$

8. Maintain signs and markers $(1,604)$

9. Imposing sanctions in the form of fines for parking offenders $(1,544)$

\section{References}

[1] A. Wadu, O. Loden, and T. Bria, "Analysis of Capacity and Level of Service (LoS) of Piet A. Tallo Street Kupang, Indonesia," 2019, doi: 10.4108/eai.18-10-2019.2289907.

[2] A. Wadu, A. A. Tuati, and M. R. Sodanango, "Strategy To Reduce Traffic Jams On Piet A. Tallo Street, Kupang City,” UKaRsT, 2020, doi: 10.30737/ukarst.v4i2.1014.

[3] J. C. Smith et al., "Projected demand and potential impacts to the National Airspace System of autonomous, electric, on-demand small aircraft," 2012, doi: 10.2514/6.2012-5595.

[4] I. Najamuddin, "Penelitian Fasilitas Bandar Udara Husein Sastranegara - Bandung," War. Penelit. Perhub., 2019, doi: 10.25104/warlit.v26i7.923.

[5] Y. Tyrinopoulos, "Public transport," in Demand for Emerging Transportation Systems: Modeling Adoption, Satisfaction, and Mobility Patterns, 2019.

[6] G. A. Funan, R. Cornelis, and E. Hunggurami, "STUDI KINERJA JALAN AKIBAT HAMBATAN SAMPING DI JALAN TIMOR RAYA DEPAN PASAR OESAO KABUPATEN KUPANG,” J. Tek. Sipil Nusa Cendana, 2014.

[7] M. S. A. G. dan J. H. Gea, "Analisis Kinerja Ruas Jalan Akibat Parkir Pada Badan Jalan ( Studi Kasus : Pasar dan Pertokoan di Jalan Besar Delitua )," J. Tek. Sipil USU, 2012.

[8] T. Rahayu, "ANALISIS KEBUTUHAN PARKIR B BANDAR UDARA INTERNASIONAL KUALANAMU ( STUDI KASUS KENDARAAN RODA EMPAT )," Educ. Build., 2017, doi: 10.24114/eb.v3i2.8262.

[9] A. Tuati, D. Daud, and A. Wadu, "Technical Study Of Bolok Crossing Port Terminal In Kupang District - East Nusa Tenggara," 2019, doi: 10.4108/eai.18-10-2019.2289913.

[10] M. M. Pandey, "Evaluating the strategic design parameters of airports in Thailand to meet service expectations of Low-Cost Airlines using the Fuzzy-based QFD method," J. Air 
Transp. Manag., 2020, doi: 10.1016/j.jairtraman.2019.101738.

[11] A. Wadu, H. Sulistio, and A. Wicaksono, "Kajian Kapasitas, Kebutuhan, dan Efektivitas Pakir di Bandar Udara El Tari Kupang," Rekayasa Sipil, 2017, doi: 10.21776/ub.rekayasasipil.2017.011.01.10. 